> Gi rask respons på artikler gjennom artikkelens kommentarfelt på tidsskriftet.no. Respons som er postet innen én måned etter at artikkelen er publisert, vurderes for publisering som Brev til redaktøren i papirutgaven.

Redaksjonen forbeholder seg retten til å foreta redaksjonelle endringer.

Forfattere av vitenskapelige artikler har tilsvarsrett, jf. Vancouver-gruppens regler.

\section{Relevante habilitetskonflikter}

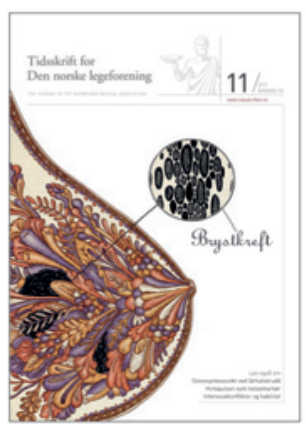

Takk for interessant artikkel i Tidsskriftet 11/2012 om habilitetskonflikter hvor det bl.a. etterlyses informasjon om håndtering av habilitet i Nasjonalt råd for kvalitet og prioritering i helsetjenesten (1). Jeg har bare en opplysning når det gjelder håndtering av habilitet $\mathrm{i}$ dette rådet. Rådet er satt sammen av ledere i helseforvaltning, de regionale helseforetak, kommunehelsetjenesten, universiteter og høyskoler, og interesseorganisasjoner. Det ble fra rådets oppstart erkjent at en generell erklæring om interessekonflikt var vanskelig å gjennomføre i praksis, med så mange «interesser» til stede. Det er derfor innført som en egen sak på saklisten til hvert møte, at eventuelle habilitetskonflikter som er relevante for dagens saker gjøres kjent i plenum, og håndteres deretter.

\section{Berit Mørland}

berit.morland@kunnskapssenteret.no

Berit Mørland (f.1942) er dr.philos., cand.odont., tidligere assisterende direktør og fagdirektør ved Nasjonalt kunnskapssenter for helsetjenesten; herunder også sekretariatsleder for Nasjonalt råd for kvalitet og prioritering i helsetjenesten. Nå pensjonist med nasjonale og internasjonale ad hoc-oppgaver.

Ingen oppgitte interessekonflikter.

\section{Litteratur}

1. Slørdal L, Eggen AE, Rygnestad T. Interessekonflikter - en kunnskapsbasert tilnærming. Tidsskr Nor Legeforen 2012; 132: 1358-60.

\section{Slørdal og medarbeidere svarer:}

Vi takker Berit Mørland for kommentar og faktaopplysninger til vår kronikk. Der etterlyste vi at sentrale beslutningstakere i HelseNorge offentliggjør sine eventuelle interessekonflikter i form av mottatte goder fra kommersielle aktører. Vi mener at en forskuddsvis innrapportering av økonomiske interessekonflikter vil øke legitimiteten til alle råds- og nemndsmedlemmer som arbeider med helsespørsmål for offentlig myndighet, og at det også vil tydeliggjøre habilitetsgrenser og -vurderinger. Vi forstår at en slik øvelse kan være ubekvem, men ikke at det er «vanskelig å gjennomføre i praksis». Hva består i så fall vanskene i?

Hvis man søker på Nasjonalt råds nettsider med søkeordet «interessekonflikt», er referater fra behandlingen av spørsmål rundt HPVvaksinering de første sakene som kommer opp. Hos de medvirkende fagfolkene finner vi interessekonflikter i form av foredragshonorarer fra vaksineprodusenter m.m., og også tilsynelatende sterkere tilknytninger. Det er vanskelig å finne ut av hvor tette disse bindingene er, siden detaljer (inkludert pengebeløp) ikke oppgis.

Vi ser også at nærvær av interessekonflikter fra ledelseshold aksepteres med formuleringer av typen «Det ble vurdert at hans deltakelse $i$ studiene hadde gitt ham en unik innsikt $i$ vaksinene, slik at verdien av dette var langt større for gruppens arbeid enn den potensielle ulempen knyttet til hans samarbeid med vaksineprodusentene» (1). Er det virkelig slik man vil ha det?
Vurderinger av interessekonflikter og habilitet er nær knyttet til hverandre. Hver enkelt persons vurdering av egen vandel når det gjelder interessekonflikter vil - slik praksis tydeligvis er i Nasjonalt råd - bestemme om vedkommende er habil i saksbehandling. «Deltakelse i studiene» utgjør en åpenbar interessekonflikt. Det er for oss vanskelig å forstå argumentet om at beslutningsprosesser blir bedre av at deltakere også har de kommersielle aktørene som oppdragsgiver.

Kjernebegrepene er «transparens» og «konsekvens». Og vanskeligere er det egentlig ikke.

\section{Lars Slørdal}

lars.slordal@ntnu.no

Anne Elise Eggen

Tarjei Rygnestad

Lars Slørdal (f. 1955) er professor i farmakologi ved Norges teknisknaturvitenskapelige universitet og overlege ved Avdeling for klinisk farmakologi ved St. Olavs hospital. Han har vært medlem av Blåreseptnemnda i perioden 2008-12.

Ingen oppgitte interessekonflikter.

Anne Elise Eggen (f. 1958) er førsteamanuensis ved Institutt for samfunnsmedisin, Universitetet i Tromsø. Hun har vært medlem av Blåreseptnemnda i perioden 2004-10 og leder i perioden 2008-10. Ingen oppgitte interessekonflikter.

Tarjei Rygnestad (f. 1954) er leder av Den rettsmedisinske kommisjon, overlege ved Nasjonalt kompetansesenter for sammensatte lidelser ved St. Olavs hospital og professor i klinisk farmakologi ved Norges teknisk-naturvitenskapelige universitet.

Ingen oppgitte interessekonflikter.

\section{Litteratur}

1. HPV-vaksine - samlet vurdering fra Nasjonalt folkehelseinstitutt. www.kvalitetogprioritering.no/Saker/_attachment/12310?_download (14.8.2012).

\section{Engelsk oversettelse ønskes!}

Takk for utmerket kronikk i Tidsskriftet nr. 11/2012 om interessekonflikter (1). Den har sikkert også relevans for ikke-norsktalende. Er det mulig å få en «offisiell» oversettelse på engelsk? Tidsskriftet har jo informert om at de nå kan publisere artikler samtidig både på norsk og på engelsk (2).

\section{Sandy Lunøe}

bareaasi@hotmail.com

Sandy Lunøe er farmasøyt.

Ingen oppgitte interessekonflikter.

\section{Litteratur}

1. Slørdal L, Eggen AE, Rygnestad T. Interessekonflikter - en kunnskapsbasert tilnærming. Tidsskr Nor Legeforen 2012; 132: 1358-60.

2. Hem E. På både norsk og engelsk. Tidsskr Nor Legeforen 2012; 132: 1201-2. 